\title{
RESIDUAL EFFECTS OF SODIUM CHLORIDE (Common Salt) FERTILIZERS ON YIELD AND LEAF NUTRIENTS, OF COCONUTS, GROWN ON AN INLAND SOIL OF DAVAO (Mindanao, Philippines)
}

by

\author{
S.S. MAGAT ${ }^{1}$, J.A. HABANA ${ }^{2}$, and L.M. ALFORJA*
}

\begin{abstract}
The beneficial residual effects of the previous regular applications of sodium chloride fertilizers on mature coconuts were evaluated in a long-term experiment conducted in an inland Tugbok soil (typic Tropudalfs) of Davao, Mindanao (Philippilines). Sodium chloride (common salt) at increpasing rates of $0.0,0.88,1.76,3.52$. and $7.04 \mathrm{~kg} /$ tree per tree was tested.,

At higher rates of $\mathrm{NaCl}$ fertilizer (1.76-7.04 kg/tree per year) applied regularly for 5 years, the residual respofise in terms of nuts and copra yield tended to, occur for a longer period of 5 years. Except soil $\mathrm{Na}$, soil. properties were not significantly affected by $\mathrm{NaCl}$ application.

Implications of the findings are discussed in relation to sound coconut crop agronomy and soil management.

\section{INTRODUCTION}

The growth and yield response or performance of the current stands of crop to fertilizers applied previously to the same stands is usually considered as residual effect(s). This is common on crops and soils applied with fertilizers containing $\mathrm{N}, \mathrm{P}, \mathrm{K}$ and $\mathrm{Na}$ as these elements tend to accumulate in the soil and plant systems, particularly at high levels and continuous application. In some instances, the residual effect from earlier fertilizer application may be depressive, probably due to nutrient imbalance (toxic) levels.

Even in recent years, very little attention has been made to the residual effects of the anion components of fertilizers as $\mathrm{Cl}$, particularly with $\mathrm{KCI}$ and $\mathrm{NaCl}$ (as source of $\mathrm{K}$ and $\mathrm{Cl}$ nutrients) application on coconut. This is attributed to the belief that negatively charged ions like $\mathrm{Cl}-, \mathrm{NO}^{3-}$, $\mathrm{SO}_{4}^{-2}$ are not adsorbed by the soil, thus easily leached down the soil profile. This is not exactly true as Magat (1985) confirmed the capability of soils to retain $\mathrm{Cl}$ by absorption in the fine structural soil regate (Tucker, 1982). After a two years cropping of Beta vulgaris der beet), high concentrations of $\mathrm{Cl}, \mathrm{Na}$ and $\mathrm{K}$ resulting from the application of $\mathrm{KCI}$ and $\mathrm{NaCl}$ were still found in the top soil $(20-40 \mathrm{~cm})$ wo silt loarn soils of New Zealand (Magat, 1985).

This paper presents an evaluation of the residual effects of two rate long-term fertilizer studies on coconut conducted at the PCA's Davao Research Center, situated in an inland area of Mindanao. Implications of the findings should be useful in the rehabilitation of ting stands of coconut; in the fertilizer management of replanted farms, as well as new plantings.
\end{abstract}

\footnotetext{
* ${ }^{1}$ Agricultural R \& D Branch, PCA, Diliman, Metro Manila.

${ }^{2}$ Davao Research Center, PCA, Bago-Oshiro, Davao City.
} 


\section{MATERIALS AND METHODS}

\subsection{Environmental Conditions}

Details of the location, climate and soil conditions of the experimental sites (both studies) have been reported (Magat et al, 1975, Magat and Padrones, 1984, Magat et al, 1987). It is located about $11 \mathrm{~km}$ (inland) from the coast, 120-160 m above sea level, with a deep and well-drained soil classified as typic Tropudalfs. The soil has : average $\mathrm{pH}$ of $6.5 ; 0.45 \mathrm{meq} \mathrm{K}, 0.11 \mathrm{meq} \mathrm{Na}, 5.7$ meq $\mathrm{Mg} / 100 \mathrm{~g} ; 70 \%$ base saturation ; clay loam surface soil and clay sub-soil (Table 1).

\subsection{Experimental Palms}

Laguna tall variety (30-35 year old) planted in $8 \mathrm{~m} \times 8 \mathrm{~m}$ square were used as experimental trees.

\subsection{Fertilizer Treatment}

The Study involved the same trees used earlier for the KCI rates study (1975-80). The five rates of $\mathrm{NaCl}$ are : $0.0,0.88,1.76,3.52$ and $7.04 \mathrm{~kg} /$ tree per year with corresponding $\mathrm{Cl}$ rates 0.0 , $0.48,0.97,1.94$ and $3.87 \mathrm{~kg} /$ tree, respectively were used. Palms received $2 \mathrm{~kg} /$ tree blanket application of $\left(\mathrm{NH}_{4}\right)_{2} \mathrm{SO}_{4}$, as $\mathrm{N}$ and $\mathrm{S}$ are also limiting coconut yields in Davao.

Fertilizers were applied in split-application at six months interval by broadcast and incorporation method, within the 1.0-1.5 m circle-weeded area of palms.

\subsection{Experimental. Design}

The five (5) $\mathrm{NaCl}$ rates replicated three times were laid out in RCBD, consisting of nine palms per treatment (plot size).

\subsection{Harvesting and Yield Estimates}

Matured nuts were harvested every 45 days ( 8 times per year) at which 20 nuts/plot were sampled for copra weight/nut as basis of copra yield (yield/tree x copra/nut).

\subsection{Sampling of Leaves and Soil}

Periodic sampling'of leaves (leaf \#14) following the procedures of Magat and Froilan, (1976) Was 'done, and samples were immediately submitted to the PCA's Tissue Analysis Laboratory. Samples were analyzed usually for concen rations of N, P, K, Ca, Mg, Na, Cl, and S. Soil sampling was done for soil analyses (some soil properties).

\section{RESULTS AND DISCUSSIONS}

Earlier (5 years ago), this study revealed that application of $\mathrm{NaCl}(0.0,0.88,1.76,3.52$ and $7.04 \mathrm{~kg} / \mathrm{tree} / \mathrm{yr}$ ), corresponding to $0.0,0.48,0.97,1.94$ and $3.87 \mathrm{~kg} \mathrm{Cl} /$ tree/yr, on local tall Taguna' coconuts grown on the $\mathrm{Cl}$-deficient Tugbok soil (Typic Tropudalfs) increased nut production, copra weigth/nut and copra yield/tree but not oil content (Magat et al, 1988). Leaf-N (\% of dry matter, (Leaf No. 14) is the main cleterminant of nut production while leaf $\mathrm{Cl}$, the one positively related to and main determinant of copra/nut and copra yield. 
Table 1. Average chemical and physical properties of the Inland Tugbok clay loan soil (Typic Tropudalf), PCA-Davao Research Centre

\begin{tabular}{|c|c|c|}
\hline PROPERTIES & SURFACE SOIL & SUBSOIL \\
\hline \multicolumn{3}{|l|}{ Chemical } \\
\hline $\mathrm{pH}\left(1: 1 /\right.$ soil: $\left.\mathrm{H}_{2} \mathrm{O}\right)$ & 6.50 & 6.70 \\
\hline Organic matter $\%$ & 1.73 & 1.40 \\
\hline Available P (ppm) & 19.00 & 11.00 \\
\hline $\begin{array}{l}\text { Total K (ppm), hot } \\
\qquad \mathrm{H}_{2} \mathrm{SO}_{4} \text { extractable }\end{array}$ & 624.00 & 687.00 \\
\hline \multicolumn{3}{|l|}{ Exchangeable cations (meq/100 g soil) } \\
\hline $\mathrm{Ca}$ & 11.40 & 12.30 \\
\hline $\mathrm{Mg}$ & 5.30 & 6.40 \\
\hline $\mathrm{Na}$ & 0.08 & 0.18 \\
\hline $\mathrm{K}$ & 0.45 & 0.29 \\
\hline CEC (m.e/100 g soil) & 25.20 & 26.70 \\
\hline Base saturation (\%) & 68.30 & 71.50 \\
\hline \multicolumn{3}{|l|}{ Physical } \\
\hline Textural grade & Clay loan & Clay \\
\hline$\%$ sand & 32.90 & 23.30 \\
\hline$\%$ silt & 33.30 & 28.90 \\
\hline$\%$ clay & 33.90 & 47.80 \\
\hline Bulk density (g/cc) & 1.58 & 1.45 \\
\hline Total Porosity (\%) & 40.60 & 45.35 \\
\hline \multicolumn{3}{|l|}{ Moisture retention capacity } \\
\hline Field capacity $(\%)$ & 32.60 & 40.60 \\
\hline Permanent wilting point $(\%)$ & 17.60 & 26.70 \\
\hline Available moisture (\%) & 14.90 & 13.80 \\
\hline
\end{tabular}

${ }^{1}$ Bago-Oshiro, Davao City, analyzed by the Bureau of Soils, Davao City

Moreover, the study showed that the optimurn econornic rate was $3.8 \mathrm{~kg} \mathrm{NaCl} /$ tree/year (yielding $125 \mathrm{nuts} /$ tree/year, $22.6 \mathrm{~g}$ copra/nut and $25.9 \mathrm{~kg}$ copra/tree or $112 \%$ increase over control palms). It was also noted that even at a low rate of $1 \mathrm{~kg} \mathrm{NaCl} /$ tree, palms produced about $18 \mathrm{~kg}$ copra/tree, while the average yield of farms in the country is about 0.85 ton copra per ha ( 8 $\mathrm{kg}$. tree/yar).

In the judicious use of common salt (substituting $\mathrm{KCl}$ as source of chloride on coconuts), it should be important to understand the post effects (residual effcts) after several years of regular application as basis of a practical and economic fertilizer management. 


\subsection{Nut Production}

Generally, nut production of fertilized palms remained at higher levels compared to unfertilized palms (Figure $\mathrm{L}$ a). However, after five years of non-application of $\mathrm{NaCl}$ (even at higher rates 3.52 and $7.04 \mathrm{~kg} /$ tree), nut production dropped drastically and these were similar to nut yields of the control palms. This suggests the positive residual effects in terms of nut production lasts only up to four years after fertilization was stopped. As nitrogen is more positively correlated to nut production than chlorine, and thus the former is the main cleterminant (Magat et al, 1988). The residual effect on nut production may be partially attribut6d to the blanket application of $2 \mathrm{~kg}\left(\mathrm{NH}_{4}\right)_{2} \mathrm{SO}_{4}$ received by palms earlier for five years.

\subsection{Copra Weight per Nut}

Figure 1.b shows that even for five years of non-application of $\mathrm{NaCl}$ fertilizers, palms applied with higher rates of $\mathrm{NaCl}(1.76-7.04 \mathrm{~kg} /$ tree) apparently maintained higher cogra weight/nut (220-260 g/ nut) compared to the control palms (140-170 g/nut). This result indicates that longer positive residual effects on copra weight per nut takes place (5 years at least), especially at higher rates $(>=1.76 \mathrm{~kg} \mathrm{NaCl} /$ tree $)$.

\subsection{Copra Yield}

High levels of copra yields, particularly for high rates of $\mathrm{NaCl} 1.76 \mathrm{~kg} / \mathrm{tree}$ ) were maintained up to four years of nonapplication of fertilizers (Figure Lc). Control palms consistently produced the lowers copra yields, however at five years after fertilization was stopped, yield of these palms were not significantly different from the $\mathrm{NaCl}$-applied palms.

As copra yield per tree is a function of both nut production and copra/nut, the decline in nut production during the fifth year (Figure 1.c) affected copra yield, even if copra weight/nut still remained high (especially at high $\mathrm{NaCl}$ rates), it therefore appears that the clear positive residual effects of $\mathrm{NaCl}$ application is stronger at higher rates of fertilization and tends to persist up to five years after the cut in the regular $\mathrm{NaCl}$ fertilization.

\subsection{Leaf Nutrient Status}

Although concentrations of $\mathrm{N}, \mathrm{K}$ and $\mathrm{S}$ in coconut leaves (leaf \#14) at 1, 2, and 3 years after $\mathrm{NaCl}$ fertilization was stopped were lower in the control palms (no previous $\mathrm{NaCl}$ applied), these levels were not significantly different from those applied with $\mathrm{NaCl}(0.887 .04 \mathrm{~kg} /$ tree $)$ as- shown in Figures 2.a, 2.b and 3.b. Leaf N, K and $\mathrm{S}$ in these years were all above the critical levels (1.8 $\% \mathrm{~N}, 0.8 \% \mathrm{~K}$ and $0.12 \% \mathrm{~S}$ ) in all treatments including -control palms. This suggests that the previous blanket-application (5 years) of $2 \mathrm{~kg}\left(\mathrm{NH}_{4}\right)_{2} \mathrm{SO}_{4}$ had maintained adequate levels of $\mathrm{N}$ and $\mathrm{S}$; and the Tugbok soil used had adequate supply of $\mathrm{K}(0.45 \mathrm{meq}$ ha/100-g soil $)$ for high yields.

However, leaf-Cl of palms applied pireviously (for 3 years) with high rates of $\mathrm{NaCl}(1.76$, 3.52 and, $7.04 \mathrm{~kg} / \mathrm{tree})$ then stopped, were within the optimum levels of $\mathrm{Cl}$. (0.50-0.60\%) (Figure 3.a). The low level of leaf-Cl in control palms $(0.08-0.15 \%)$ and palms receiving only $0.80 \mathrm{~kg}$ $\mathrm{NaCl}$ (especially at the third year) were below the critical level of $(0.30 \%)$. These resulted in very low copra weight per nut and copra yield of palm as mentioned earlier (Section 3.2 and 3.3). At higher rates of $\mathrm{NaCl}$ (1.76-7.04 kg/tree), longer positive residual effects was reached mainly due to higher concentrations of leaf-Cl maintained by palms, associated with significantly higher copra weight (per nut) and copra yield (per tree). 
Clearly, palms without sodium chloride application remained strongly deficient in $\mathrm{Cl}$ $(0.10 \% \mathrm{Cl})$ over the observation period. Moreover, the nutrient $\mathrm{Cl}$ absorbed by palms from the fertilizer applied to soil has a very long persistency in the coconut plant system, resulting to at least 5 years positive residual effect on coconut. Leaf $\mathrm{Cl}$ is positively correlated with high copra yield (Ollagnier and Ochs, 1971; Uexkull, 1972; Mendoza and Prudente, 1972; Magat et al, 1975, Margate et al, 1979).

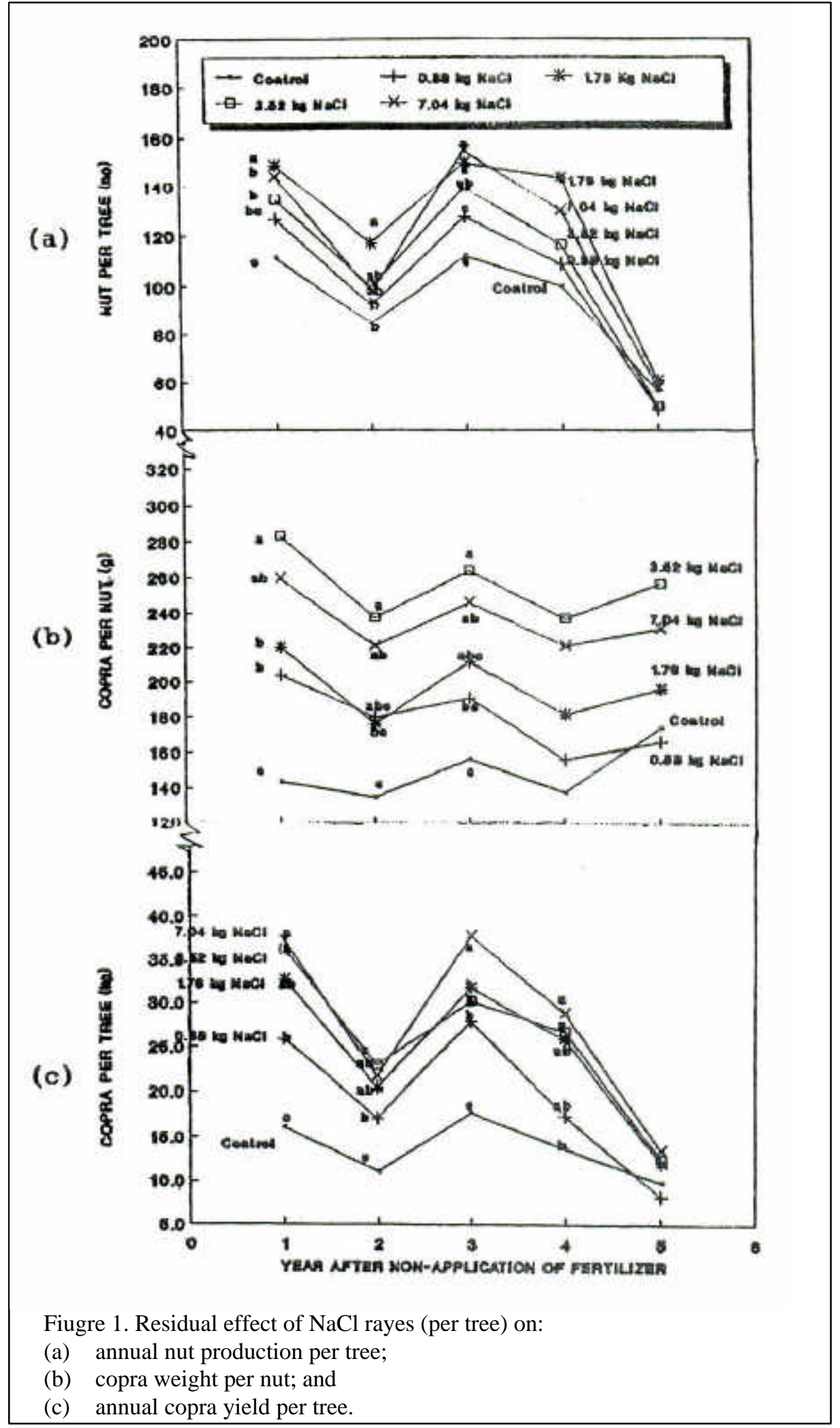




\subsection{Some Soil Properties}

Five years after the $\mathrm{NaCl}$ fertilization cut, soil properties (topsoil and subsoil) as $\mathrm{pH}$, organic, matter, electrical, conductivity, waterholding capacity, CEC, available $\mathrm{P}$, total $\mathrm{K}$, exchangeable bases $(\mathrm{Ca}, \mathrm{Mg}$ and $\mathrm{K}$ ) were not significantly different from the control, even in treatments applied with high rates of $\mathrm{NaCl}(3.52 \mathrm{~kg}$ and $7.04 \mathrm{~kg} /$ tree/year) (Tables 2.1 and 2.2). However, for soil $\mathrm{Na}$, especially at the two higher rates, levels remained still high, but the soil bulk density did not significantly vary, indicating that the rates applied of $\mathrm{NaCl}$ (0.88-7.04 $\mathrm{kg} /$ tree) did not result in destruction of soil structure as reflected through the bulk density $(1.41-1.51 \mathrm{~g} / \mathrm{cc})$ (Table 2. 1).

The levels of salinity and $\mathrm{Na}$ as indicated by electrical conductivity (EC) and exchangeable $\mathrm{Na}$ are considered way below the critical or excessive levels of EC $40 \mathrm{mmhos} / \mathrm{cm}$ and $>0.50 \mathrm{Na}$ $\mathrm{meq} / 100 \mathrm{~g}$ soil.

The clear increased in soil acidity (decreased $\mathrm{pH}$ ) in all treatments including the control was likely due to the earlier application (5 years) of $2 \mathrm{~kg}\left(\mathrm{NH}_{4}\right)_{2} \mathrm{SO}_{4}$. At $\mathrm{pH} 5$, coconut still grows and produce normally. Moreover, it strongly appears that soil $\mathrm{P}$ and exchangeable bases $(\mathrm{K}, \mathrm{Ca}, \mathrm{Mg})$ are still highly adequate for the palms.

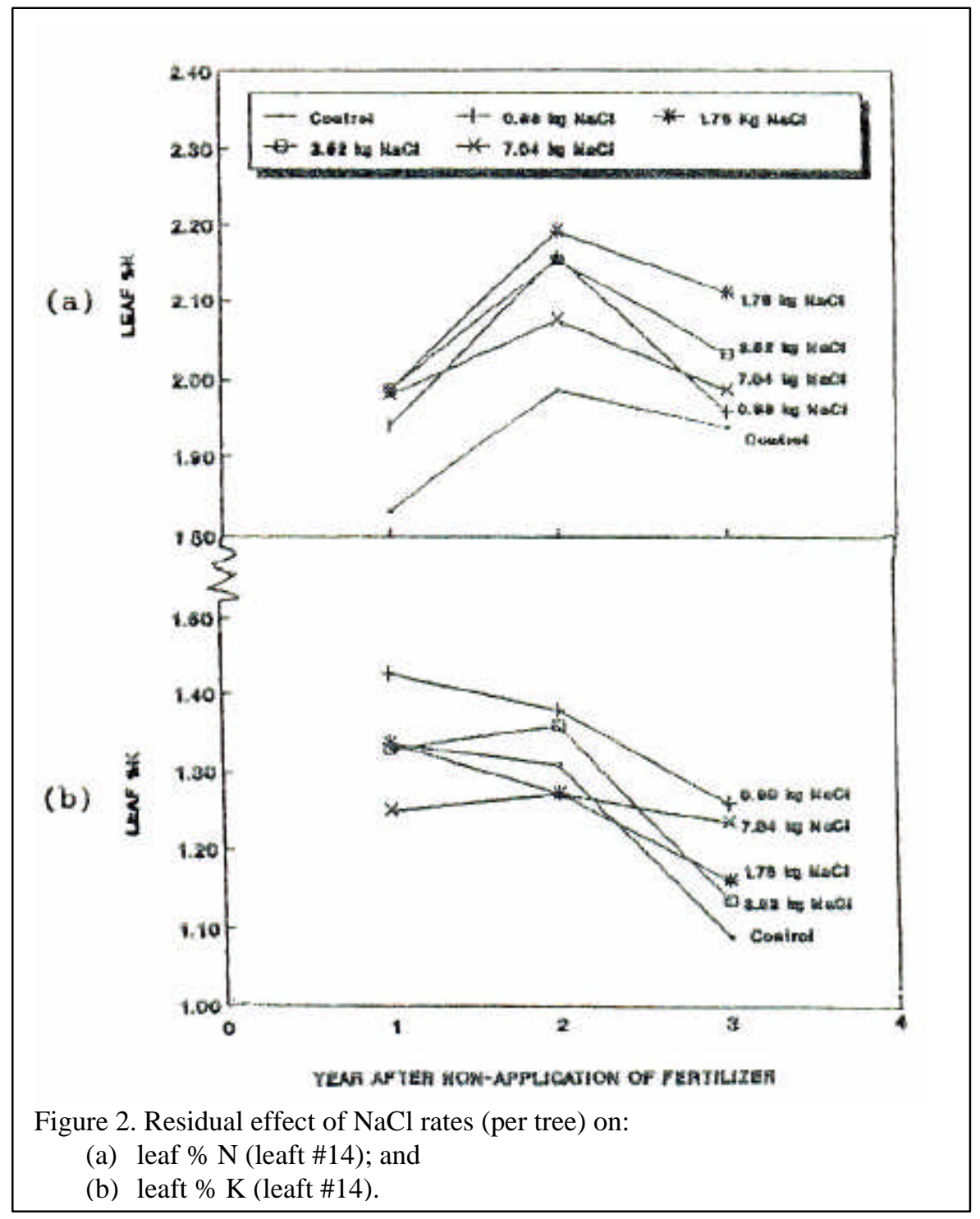




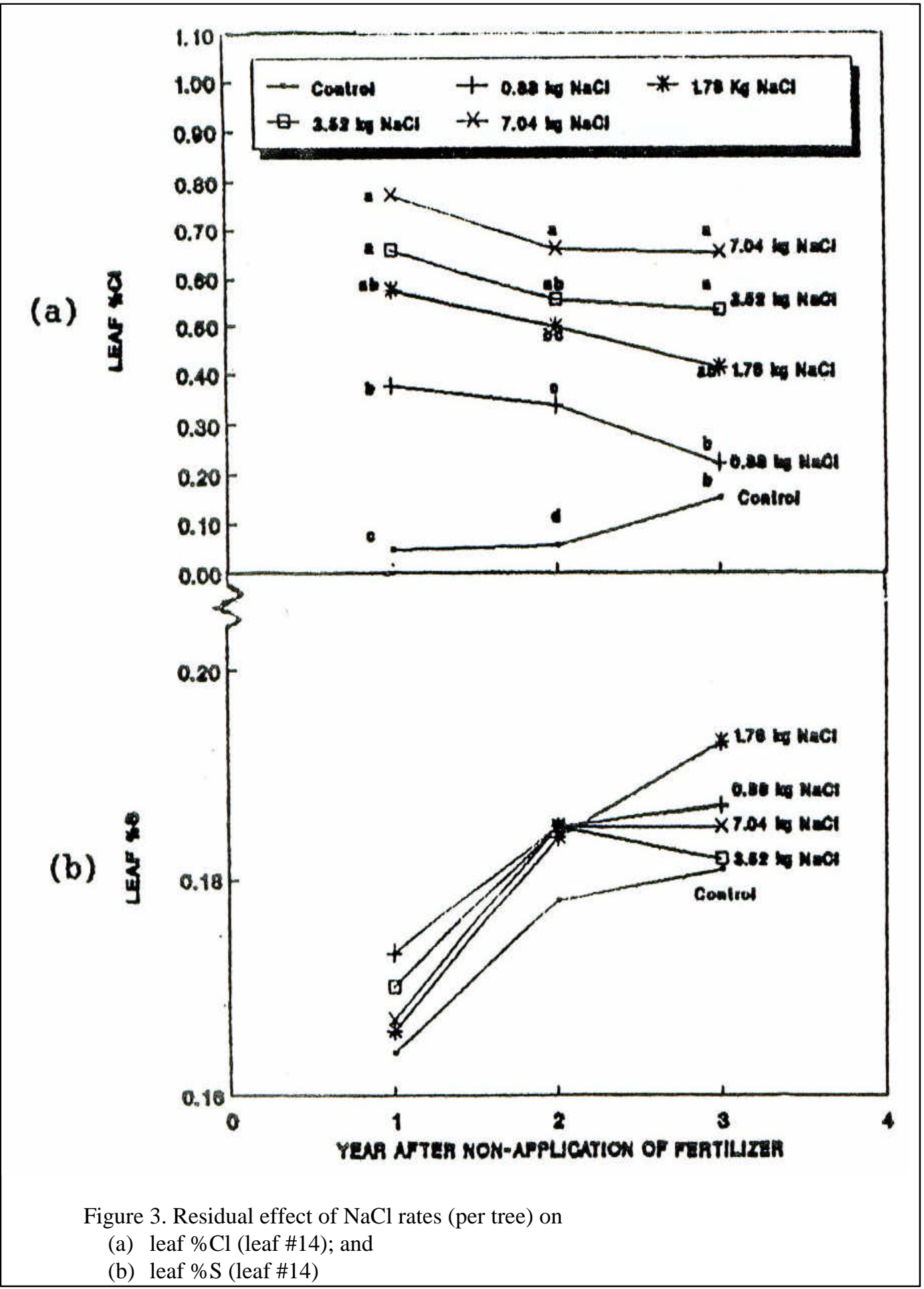


Table 2.1 Soil Properties as effected by previous $\mathrm{NaCl}$ application (5 years) at increasing rates as observed 5 years after, February 1991

\begin{tabular}{|c|c|c|c|c|}
\hline \multirow{3}{*}{$\begin{array}{l}\text { NaCl RATE } \\
(\mathrm{Kg} / \mathrm{tree} / \mathrm{yr})\end{array}$} & \multicolumn{4}{|c|}{ SOIL PROPERTIES } \\
\hline & \multicolumn{2}{|c|}{$\underline{\text { Soil pH}}$} & \multicolumn{2}{|c|}{$\underline{\text { Organic matter }(\%)}$} \\
\hline & Topsoil & $\underline{\text { Subsoil }}$ & $\underline{\text { Topsoil }}$ & $\underline{\text { Subsoil }}$ \\
\hline$\overline{0.0}$ & 4.96 & $\overline{5.50}$ & 2.05 & 1.28 \\
\hline 0.88 & 5.10 & 5.50 & 1.95 & 1.39 \\
\hline 1.76 & 5.13 & 5.56 & 2.01 & 1.36 \\
\hline 3.52 & 5.20 & 5.50 & 1.95 & 1.22 \\
\hline 7.04 & 5.03 & 5.43 & 2.21 & 1.34 \\
\hline \multirow{4}{*}{$\begin{array}{l}\text { S.E. mean } \\
\text { C.V. }(\%) \\
\end{array}$} & 0.17 & 0.13 & 0.16 & 0.07 \\
\hline & 5.80 & 4.01 & 13.40 & 9.20 \\
\hline & \multicolumn{2}{|c|}{$\mathrm{EC}(\mathrm{mmhos} / \mathrm{cm})$} & \multicolumn{2}{|c|}{ Exchangeable $\mathrm{Na}(\mathrm{meg} / 100 \mathrm{~g})$} \\
\hline & $\underline{\text { Topsoil }}$ & $\underline{\text { Subsoil }}$ & Topsoil & $\underline{\text { Subsoil }}$ \\
\hline 0.0 & 0.227 & 0.203 & $0.12 \mathrm{ab}^{*}$ & 0.34 \\
\hline 0.88 & 0.207 & 0.223 & $0.08 \mathrm{~b}$ & 0.23 \\
\hline 1.76 & 0.230 & 0.230 & $0.15 \mathrm{ab}$ & 0.27 \\
\hline 3.52 & 0.217 & 0.247 & $0.30 \mathrm{a}$ & 0.39 \\
\hline 7.04 & 0.213 & 0.257 & $0.24 \mathrm{ab}$ & 0.71 \\
\hline \multirow{4}{*}{$\begin{array}{l}\text { S.E. mean } \\
\text { C.V. }(\%)\end{array}$} & 0.016 & 0.069 & 0.04 & 0.11 \\
\hline & 12.3 & 9.2 & 43.0 & 52.0 \\
\hline & \multicolumn{2}{|c|}{$\underline{\mathrm{WCH}(\%)}$} & \multicolumn{2}{|c|}{ Bulk density (g/cc) } \\
\hline & $\underline{\text { Topsoil }}$ & $\underline{\text { Subsoil }}$ & Topsoil & $\underline{\text { Subsoil }}$ \\
\hline 0.0 & 61.30 & 64.30 & 1.48 & - \\
\hline 0.88 & 64.20 & 65.30 & 1.51 & - \\
\hline 1.76 & 61.00 & 64.50 & 1.43 & - \\
\hline 3.52 & 62.40 & 66.50 & 1.41 & - \\
\hline 7.04 & 61.70 & 66.40 & 1.50 & \\
\hline S.E. mean & 1.26 & 1.16 & 0.03 & - \\
\hline C.V. $(\%)$ & 3.5 & 3.1 & 3.3 & - \\
\hline
\end{tabular}

* Means followed with same letter(s) are not significantly differenct (5\% level of statistical significance) 
Table 2.2. Soil Properties as affected by previous $\mathrm{NaCl}$ application (5 years) at increasing rates, as observer 5 years after, February 1991

\begin{tabular}{|c|c|c|c|c|}
\hline \multirow{3}{*}{$\begin{array}{l}\text { NaCl RATE } \\
(\mathrm{Kg} / \text { tree/yr) }\end{array}$} & \multicolumn{4}{|c|}{ SOIL PROPERTIES } \\
\hline & \multicolumn{2}{|c|}{ CEC meg/100g } & \multicolumn{2}{|c|}{ Available P ppm (Olsen) } \\
\hline & Topsoil & Subsoil & Topsoil & $\underline{\text { Subsoil }}$ \\
\hline 0.0 & 23.80 & 24.10 & 20.30 & 16.60 \\
\hline 0.88 & 24.10 & 34.70 & 13.30 & 11.30 \\
\hline 1.76 & 24.10 & 25.90 & 32.60 & 23.00 \\
\hline 3.52 & 24.10 & 23.70 & 15.00 & 16.00 \\
\hline 7.04 & 23.70 & 23.50 & 18.00 & 14.60 \\
\hline \multirow{4}{*}{$\begin{array}{l}\text { S.E. mean } \\
\text { C.V. }(\%)\end{array}$} & 0.76 & 3.89 & 5.40 & 3.80 \\
\hline & 5.5 & 25.5 & 47.8 & 40.8 \\
\hline & \multicolumn{2}{|c|}{ Total K (ppm) } & \multicolumn{2}{|c|}{ Exchangeable $\mathrm{Ca}(\mathrm{meg} / 100 \mathrm{~g})$} \\
\hline & Topsoil & $\underline{\text { Subsoil }}$ & Topsoil & $\underline{\text { Subsoil }}$ \\
\hline 0.0 & 880 & 746 & 9.07 & 9.73 \\
\hline 0.88 & 1053 & 973 & 7.76 & 9.00 \\
\hline 1.76 & 783 & 686 & 8.79 & 10.25 \\
\hline 3.52 & 1116 & 750 & 8.37 & 9.65 \\
\hline 7.04 & 586 & 1326 & 7.95 & 7.51 \\
\hline S.E. mean & 267 & 176 & 0.83 & 0.72 \\
\hline \multirow[t]{3}{*}{ C.V. $(\%)$} & 52 & 34 & 17.1 & 13.9 \\
\hline & \multicolumn{2}{|c|}{$\frac{\text { Exchangeable } \mathrm{Mg}}{(\mathrm{meg} / 100 \mathrm{~g})}$} & \multicolumn{2}{|c|}{$\frac{\text { Exchangeable } \mathrm{K}}{(\mathrm{meg} / 100 \mathrm{~g})}$} \\
\hline & Topsoil & Subsoil & Topsoil & $\underline{\text { Subsoil }}$ \\
\hline 0.0 & 2.05 & 2.92 & 2.07 & $2.33 \mathrm{ab}$ \\
\hline 0.88 & 2.77 & 3.31 & 1.56 & $0.88 \mathrm{c}$ \\
\hline 1.76 & 2.24 & 2.42 & 1.60 & $1.45 b c$ \\
\hline 3.52 & 2.55 & 3.08 & 1.82 & $1.86 \mathrm{bc}$ \\
\hline 7.04 & 1.14 & 1.96 & 2.69 & $3.22 \mathrm{a}$ \\
\hline S.E. mean & 0.43 & 0.63 & 0.28 & 0.22 \\
\hline C.V. $(\%)$ & 34.3 & 38.1 & 25.7 & 19.8 \\
\hline
\end{tabular}

\section{CONCLUSION}

With $\mathrm{NaCl}$ application, the positive residual effects on copra (weight/nut and yield/tree/year) could last for longer period (4-5 years) at fertilization rates of $>=1.76 \mathrm{~kg} \mathrm{NaCl} /$ tree $(0.97-3.87 \mathrm{~kg}$ $\mathrm{Cl} /$ tree/year).

Based on the soil bulk density, exchangeable $\mathrm{Na}$ and salinity index (EC), even at higher $\mathrm{NaCl}$ rate $(3.52 \mathrm{~kg}$ and $7.04 \mathrm{~kg} /$ tree), no apparent adverse effects are, observed. The maintenance or persistence of beneficially high levels of leaf- $\mathrm{Cl}$ in coconuts as a.result of the previous application could either or both be likely due to nutrient recycling within the soil and crop systems, common in long-term, cropping or production of perennials.

In the rehabilitation of existing stands of coconut or newly established farms, findings of this study on the existence of positive residual effects of Sodium chloride fertilization implies that with 3-5 years of regular fertilization, the next 3-5 years very likely requires no fertilization at all due to the build-up of nutrients within the plant system, physiologically and agronomically speaking. 
Because of the savings from non-fertilization, margin of profit should be expected, considering also that high nut and copra yields are maintained due to the positive residual effects of sodium chloride fertilizers.

\section{ACKNOWLEDGEMENT}

We are very grateful for the assistance of Ms. Lucita Lina and her staff (Tissue Analysis Laboratory, PCA) in the analysis of leaf samples. Likewise, to Mr. Maximino Gelborion (Davao Research Center), for the careful gathering of research field data; and finally, to Ms. Rhoda A.P. Prudente (PCA-ARMD) for the computerized typing of the manuscript.

\section{REFERENCES}

Magat, S.S., V.L. Cadigal and J.A. Habana. 1875. Yield improvement of coconut in elevated inland area of Davao by KCI fertilizer. Oleagineux 30(10) : 413-418.

Magat, S.S. and G.D. Padrones. 1982. Effects of the various sources of chloride and nitrogen on the growth and production of bearing coconuts (p. 16-34). In : Annual Report, Agricultural Res., Phil. Coconut Authority. 243p.

Magat, S.S. and G.D. Padrones. 1984. Initial respqnse of young bearing palms to various sources of chlorine. Phil. J. Coconut Studies 12

21-29.

Magat, S.S. 1985. Field studies on some effects of chlorine fertilizers on the growth, yield and nutrient status of fodder beet (Beta vulgaris L.) and on some soil properties of two New Zealand Soils. Ph.D. Thesis, Lincoln College, University of Canterbury, New Zealand.

Magat, S. S., L. M. Alforja and R. Z. Margate. 1988. An estimate of the optimum and critical levels of leaf-S concentrations in bearing coconuts (local tall). Phil. J. Coconut Studies 13(l) : 6-9.

Magat, S.S., R.Z. Margate and J.A Habana. 1988. Effects of increasing rates of Sodium chloride fertilization on coconut yield under an inland soil of Mindanao, Philippines. Oleagineux 43(1) :14-20.

Magat, S.S., L.M. Alforja and L.G. Oguis. 1989. An estimation of the critical and optimum levels of leaf $\mathrm{Cl}$ in bearing coconuts A guide for foliar diagnosis. Phil. J. Coconut Studies 13(1) : 6-9.

Magat, S.S. and G.D. Padrones, t991. Improvement of Coconut Production by combined potassiurn chloride and ammonium sulfate fertilization in a low-yielding area of Northern Mindanao, Philippines. Phil. J. Coconut Studies. 3(1): 37-44.

Margate, R.Z., S.S. Magat, L.M. Alforja, and J.A. Habana. 1979. A Long-Term KCI fertilization of bearing coconuts in an inlandupland area of Davao. Oleagineux 34(5) : 235-240.

Mendoza, A.M.R. and R.L. Prudente. 1972. Fertilization Studies on Coconut at the PHILCORIN. Proc. Nat. Science and Tech. Week, Manila.

Ollagnier M. and R. Ochs. 1971. Chlorine, a new essential in coconut and oil palm nutrition. Oleagineux. $26: 1-15$. 
Tucker, B.M. 1982. Interaction of chloride with soil-a factor in self retention by saline soils. Australian J. of Soil Research $20: 325-337$.

Von Uexkull, H.R. 1972. Response of coconuts to (potassium) chloride in the Philippines. Oleagineux $27: 13-19$.

\section{SHORT NOTE ABOUT THE AUTHORS}

Dr. SEVERINO S. MAGAT, Department Manager III, PCA, with the rank of Scientist IV in the Philippines Scientific Career System and has been very active in coconut research, especially in the field of Soils and Crop Nutrition, and Crop Agronomy for the past 20 years. His works have been widely published locally and internationally.

Mr. Jesus A. Habana, Science Research Specialist II PCA, has worked with Dr. Magat for the past 17 years and his research findings with practical field use have been also widely disserninated

Mr. LEON M. ALFORJA, Division Chief III, PCA, with expertise in Biometry for the past 19 years has provided a clear understanding of research data on experiments involving soils and crop nutrition, and agronomy published and documented by PCA, locally and internationally. 